\title{
THE DEVELOPMENT OF KINGSHIP INSTITUTION IN ORU-IGBO UP TO 1991
}

\author{
Ugo Pascal Onumonu* \\ http://dx.doi.org/10.4314/og.v12i 1.4
}

\section{Abstract}

The saying "Igbo do not have kings"- Igbo enweeze (Jell-Bahlsen:13) is undoubtedly one of the most profound statements in Igbo proverbs. Nevertheless, facts predicated on historical evidences have proven that kingship institution existed in Igboland since the pre-colonial period. However, this claim cannot be generalized since it is not applicable to all parts of Igboland. In other words, this simply implies that there are some parts of Igboland whose people could be regarded as the genuine custodians of kingship institution as an imperishable heritage right from the pre-colonial through post-colonial eras. On this basis, therefore, this paper interrogates the development of kingship institution in Oru-Igbo with a view to bringing to the fore the knowledge of kingship institution that existed in Oru-Igbo at different epochs. Therefore, Oru-Igbo are one of the people that had kings in the pre-colonial, colonial and postcolonial eras in Igboland as considered in this paper within the period which this discourse focuses on. The knowledge and practice of kingship as an institution are not alien cultures to the Oru-Igbo. The paper examines their relationship with the Igbo at the West of the Niger (today's Delta State of Nigeria) as well as the Benin people of Nigeria in terms of kingship hence it is a common belief in Oru-Igbo that they migrated from a place called Ado naIdu ${ }^{1}$ in the $15^{\text {th }}$ century. The paper also investigates the essence of $\mathrm{Oru}^{2}$ or why the people of Oru-Igbo pride themselves as Oru-Igbo instead of strictly identifying themselves as Igbo without the "Oru or Oruness" appendage as they often do when the need arises or when it becomes necessary to accentuate their peculiar culture such as the kingship institution. Interestingly, apart

\footnotetext{
${ }^{1}$ Ado naldu is located somewhere in-between the boundary of present Edo and Delta States.

${ }^{2}$ Oru or Oru-lgbo as the case may be is not to be confused with Oru, slave. The term is an umbrella name for Riverine Igbo found in today's South-South and South-East of Nigeria.
} 
from such issues that touch the identity and culture of Oru-Igbo which are regarded as identity makers, Oru-Igbo people do not on concrete and practical terms disassociate themselves from Igbo nation. Towards this end, the paper interrogates the peculiar kingly culture of Oru-Igbo in the South East ( East of the Niger) of Nigeria and how such legacy endured over the years and practically distinguished them from other hinter land Igbo, most especially with respect to culture. Also, in this paper, however, it is discovered that the Oru-Igbo are unarguably Igbo irrespective of their cultural inclination and some other factors that made other "Igbo" create a new identity in the post Nigeria-Biafra civil war of 1967-1970 by declaring themselves as non -"Igbo".

\section{Introduction}

Without doubt, one of the most outstanding features of Oru-Igbo society at different epochs is kingship institution. It is equally regarded as a long standing institution given its many years of existence. According to Oru-Igbo myth, the need for all communities comprising of Oru-Igbo to have their own king arose when they left Benin ${ }^{3}$ for Ado naIdu. OruIgbo people left Benin for Ado naIdu when there was a misunderstanding between the Ika Igbo (non-Benin indigenes) ${ }^{4}$ and the

\footnotetext{
${ }^{3}$ Nevertheless, based on the convincing views of most emerging intellectuals in Oru-lgbo who have thoroughly investigated the popular opinion on the age-long held view regarding Benin as Oru-Igbo place of origin, it appears that Benin was simply one of the places Oru-lgbo people settled in the course of their sojourn in the Western Igboland in the pre-colonial era. Their contact with the Benin could be seen as part of their migration experience. With the wealth of influence Benin Empire had over her surrounding neighbours and even those far away from Benin, it is expected that all kinds of social movements would have taken place.

${ }^{4}$ At Ado naldu and other parts of Western Igboland (today's Delta State) including Benin itself which they equally settled in the pre-colonial period, Oru-lgbo and their other kith and kin were known as Ika-lgbo which means non Benin indigenes. Based on this revelation, one can easily dismiss the claim made by some Igbo who reject their Igbo identity simply because they once had contact with the Benin people at one point in history like the Oru-Igbo in the Western Igboland during the pre-colonial days.
} 
Benin indigenes. The first to leave Ado naIdu among the larger group 5 of Oru-Igbo was Onitsha people who left Benin for Ado naIdu in 1401 (Onumonu,2012:88). The event, as it were, led to the massive convergence of various Ika-Igbo in the region (Ado naIdu). Consequent upon this development, the various communities in Oru-Igbo decided to establish their own separate kingship institution which became an OruIgbo affair in its entirety in 1461. The above referred misunderstanding which took place in the $15^{\text {th }}$ century acted as a catalyst that propelled the establishment of an exclusive Oru-Igbo kingship and their subsequent roll back migration to Oguta area in today's Imo State of Nigeria. (Onumonu,2012:88)

Furthermore, all the founding fathers of the riverine kingdoms are reputed to have resided in Benin from where they took off after some conflicts with the Benin kingdom. Their migrations which followed such departures are replete with legends of settlements at successive points before arrival at the present site $^{6}$. One prominent

${ }^{5}$ The larger group of Oru-lgbo comprises of other riverine Igbo who also have distinct culture slightly different from other Igbo at the hinter land of Igboland. For example, Ogbaru and Onitsha people in today's Anambra State are riverine Igbo who share this "Oru-Igboness" idea. Others are Igbo in today's Delta State, especially those domiciled around the River Niger of Nigeria.

${ }^{6}$ The present site as seen above refers to the Oguta area in today's Imo State of Nigeria. The location stretches from the area Eziorsu community occupies down to the area Mgbele community occupies on the northern part of the lake. Oguta community is located on the southern part of the Oguta Lake. OrsuObodo, Kalabari Beach/Aro Quarter, Nnebukwu and Nkwesi are also located at the northern part of the lake. In addition, it is important to stress that the Kalabari Beach/Aro Quarter community became part of Oru-lgbo in the present location and not from the Western Igboland as a result of their long settlement and association with the Oru-Igbo which eventually led to their integration into Oru-Igbo community. Today, they are also regarded as Oru-lgbo. Interestingly, it is also very important to state that all the communities comprising of Oru-Igbo including the KalabariBeac/Aro Quarters are all contiguous, knitted together in a distinct ecological, cultural and 
feature of these migrations, which distinguished them from those of the Nri core, was that they gave prominence to particular individuals who later established themselves as kings and whose children then constituted the royal lineage (Imoagene,1990:14-15). In other words, there were monarchies in areas like; Oru-Igbo (Oguta area), Western Igboland (some areas in today's Delta State), Onitsha and Ogbaru areas. There were the Obis among the Western Igbo and Onitsha. Presiding over the whole community was the king (Ojiakor,1996:18). Nevertheless, the king did not rule in isolation. Though he was regarded as the father of all, he was not an absolute king. This implies that the leadership of the people was not a "one man affair". He was, therefore, considered as the representative of the people or what one can regard as being first among equals: kingly officials. He had the mandate to lead but had to work with some selected men who were endowed with the requisite knowledge of government, diplomacy and administration. The king was charged with the responsibility of steering the ship of governance with great sense of responsibility. He was not in any way allowed to impose himself on his people. The selected men who jointly gave kings incredible support were the cultural titles holders and kingly officials. In view of this, it could be said that, the act of governance was made easy to a very reasonable extent. The above-mentioned officials had various constitutional functions which distinguished them from the rest of the public. The king as a matter of fact, was required to consult the cultural title holders and kingly officials who were part of his government before taking an important decision. Therefore, it could be affirmed that the complementary relationship that existed between the cultural title holders and the king reflects the robust political structure that existed in Oru-Igbo.

The encounter and experience Oru-Igbo people had with divergent cultures at different historical epochs informed the kind of kingship institution that evolved among Oru-Igbo communities. This does not in any way suggest or mean that Oru-Igbo did not have an established kingship system prior to their contact with the Benin people

linguistic zone with freshwater riverine terrain and humid tropical rainforest environment. 
in the pre-colonial period. Their contact with other cultures, such as Benin culture, offered them the opportunity to blend their culture with other cultures as that is always the outcome of interaction. Unlike their close hinterland neighbors, Oru-Igbo developed a well structured monarchy that guaranteed smooth administration. In generalization, it is often inferred or said that the Igbo did not have a well structured kingship system from the pre-colonial era. This, however, cannot be said of Oru-Igbo as they evidently represent an exception to this general rule. Indeed, the kingly culture was part of their experiences in the various places they lived such as; Benin, Ado naIdu (somewhere around the boundary between today's Delta and Edo States), Illah, Ndosimili area and other Western Igboland in the lower Niger of today's Delta State and their permanent abode in Oguta area of Imo State. (Onumonu, 2012:87)

\section{The People of Oru-Igbo and the Conceptualization of Oru}

Geography has, just like in other places, played a major role in shaping the culture and history of Oru-Igbo. The Oru-Igbo people are part of an Igbo stock with riverine culture (Odili, 1985:3). They live close to the river with a very rich history (Eyisi, 2010:6). Traditionally, their main two occupations are fishing and farming which take place all through the year. All the communities that make up Oru-Igbo are covered in lush green vegetation. The water body that enhances rain falls in turn flourishes the vegetation. Therefore, there is no shortage of water in Oru-Igbo. (N.A.E:5). They do not lack food or fish because their fertile lands produce bountifully while the river serves as the source of fish. The Oru-Igbo in Imo State with common cultural affinity occupy seven communities in Oguta Local Government Area. The towns are: Eziorsu, Oguta, Kalabari Beach/ Aro Quarter ${ }^{7}$, OrsuObodo, Nnebukwu, Nkwesi

\footnotetext{
${ }^{7}$ Kalabari is a name of a tribe in Rivers State. The Kalabari people were attracted to Oru-Igbo (Oguta area) in the $18^{\text {th }}$ century following the commercial activities of the British which led to the investment of various British companies in Oru-Igbo involving; United Africa Company (U.A.C.), Miller Brothers, G.B. Ollivant, John Holt etc. These European companies traded on palm oil. Before the period of palm-oil boom, there was an influx of kalabari men from Abonema, Buguma into Oru-Igbo mainly for trade. These
} 
and Mgbele. ${ }^{8}$ The popular opinion of the Oru-Igbo is in support of Benin or Edo migration and some of them believe that they have Benin origin. Nevertheless, some of them insist that their origin has nothing to do with Edo or Benin but agree that they at some points in history settled there and migrated back to Oguta area in the pre-colonial era. ${ }^{9}$

Though there are other Oru-Igbo in the South South and South East of Nigeria but Oru-Igbo as an umbrella name for sub-cultural Igbo group predates the colonial era. Tracing the exact date of its adoption would be a difficult task. The word "Oru-Igbo" is an embracing name for all the riverine Igbo with a similar culture. Generally, Oru-Igbo people are referred to as Oru-Igbo in Igboland not because they are not Igbo but because of their rich ecology and culture. The riverine Igbo distinguish themselves from the other Igbo, above all, on account of the institution of Obi, Ezeigwe, or sacred king (Jell-Bahlsen, 2008:13). When an assemblage of Igbo is being addressed, it is addressed as Oruna-Igbo:Oru and Igbo. Oru-Igbo distinct ecology establishes in OruIgbo the familiarity with fresh water (riverine terrain) and humid tropical rainforest environment. One could deduce from the foregoing that the meaning of Oru connotes a mark of identity promoted by OruIgbo with the sole aim of announcing their riverine culture and affinity with the Western Igbo and Benin people.

people with their wealth of experiences in palm oil trade obtained through their earlier contact with the European traders in today's Delta State were able to monopolise the trade. The trade became very enterprising in the $19^{\text {th }}$ and $20^{\text {th }}$ centuries and attracted various people of different ethnic origins in the above-mentioned period. (Ndupu,2001:96-97) However, at the eve of the Nigerian civil war of 1967-1970, the Kalabari people returned to Rivers State leaving other settlers who came from different parts of Igboland. The other settlers are still living in Oru-lgbo till date. Since then, the area has been known as Kalabari Beach/AroQuater.

${ }^{8}$ For the sake of focus, the paper mainly concentrates on the Oru-Igbo in Oguta Local Government Area. They have other kith and kin in Rivers, Anambra, Delta, Abia and Imo States who share similar culture and history with them.

${ }^{9}$ Ndupu Felix Chukwudifu, (65 years) of Oguta Community, OgutaL.G.A.,Imo State, interviewed on $30^{\text {th }}$ July, 2015 at Ibadan. 
The Igbo are one of Nigeria's largest ethnic groups, conservatively estimated to number about 20 million, with potentially up to 100 million members worldwide, united by a common language and culture with local variations in custom and dialects. (JellBahlsen,2008:13) Igboland is among the most densely populated in Africa, with intense agricultural productivity and several large urban centres. The Igbo people are regarded as a nation, located in several states within the modern nation-state of Nigeria (Jell-Bahlsen,2008:13).

Having established that the Oru-Igbo are part of Igbo nation, it is imperative to point out that the Oru-Igbo in Oguta L.G.A. have a very peculiar culture that makes other hinterland Igbo to often assume or conclude that they are not Igbo. Despite their cultural affinity and similarity with the Onitsha who are also riverine Igbo with Benin contact, there are important linguistics differences that exist between both of them in terms of dialect. Nevertheless, Onitsha and Oru-Igbo always refer to their cultural affinity and common history in their interaction.

The Oru-Igbo word for "water" is mmiri, in Onitsha it is mmili, and the Oru-Igbo in Oguta L.G.A. understand the Onitsha and central Igbo saying, dalu,i.e thank you, the Oru-Igbo themselves say mbuana, instead, a phrase not immediately understood by those from other parts of Igboland. Despite these and other differences, the Oru-Igbo also share many major cultural and linguistic features with the entire Igbo ethnic group. As other Igbo subdivisions, they value the "kola hospitality", respect the authority of persons, such as elders or priest who are entitled to hold a special wand of office, the ofo and observe a calendar of four named week days: Eke, Orie, Afor, and Nkwo, corresponding to the timing of the local markets and all other economic and ritual activities in correspondence to a four-or eight-day rhythm respectively (Jell-Bahlsen, 2008:15).

\section{The Status of Ezeigwe in Oru-Igbo}

The Ezeigwe of Oru-Igbo, also known as Obi, was constitutionally regarded as the leader of all. He discharged his supreme legislative and judicial functions with the help of title officials and elders. He was seen as the symbol of unity for the different agnatic groups. Thus, the Ezeigwe could be removed or disciplined because he was not the pivot 
of economic arrangements as the Oba of Benin. The Obi could not collect taxes, tolls, or engage in any economic activity whatsoever unlike the lesser kings (Odili, 1985:15-16). Except for the Iyasara (Prime Minister), anyone who came before the Obi bowed as a mark of respect. The Obi's court was the appellate court for the courts of all other officialls, and he had exclusive jurisdiction in cases of homicide. Beyond these responsibilities, there was hardly any room for independent political action by the Obi. The military commander (the Ndanike) could wage war on his own if he so desired. The Obieze (Village Assembly), analogous to the village assembly of the classical segmentary lineage system, was the highest legislative and policymaking body. Although the Obieze was held in his palace, the Obi "had no say in the deliberations. He was a silent on-looker." (Falola, 200:288) The Obieze was usually directed by the Ogana, one of the kingly officials. Indeed, the Obi shared with the other officials the prerogatives which set him apart from the rest of the society. In most cases, the king's role was limited by the actual structure of government: he could hardly take any independent action on any matter. The Obi worked with kingly officials in discharging his duties. In accordance to hierarchy, the Iyasara (prime minister) was the next to the Obi or Ezeigwe in Oru-Igbo. In addition to these, there were two other colleges of titled men, the Oririnzere and the ndiokpara. The latter were the heads of the lineages in Oru-Igbo. As in Onitsha, each position was invested in a specific lineage (Falola, 200:288).

In addition, to prevent monarchical absolutism and political tyranny, there evolved mechanism like the king's council of chiefs with a decisive voice in the king's investure, powerful secret societies in which the king was only first among equals. All of these, coupled with the intangible but effective factor of public opinion, served to protect law and custom by controlling the arrogation of royal power (Falola, in Onumonu, 2012:94). In view of the above, it is evident that the status of the Ezeigwe in Oru-Igbo was clearly defined. The structure of the kingship was organized such that the king did not see himself as an absolute ruler who would lead without the consent of other kingly officials and other stakeholders. The king was regarded as the first among equal and not an absolute ruler as some Europeans generally 
regarded African traditional rulers. The fact that the status of the king was defined shows that the tradition of following the laid down process in the act of governance was upheld. Without doubt, it suggests that to a very great extent the act of governance (or democracy) was not a foreign culture to Oru-Igbo. Hence the kingship structure had a measure that ensured the king did not cross his political boundary. It, therefore, implies that Oru-Igbo had a well structured system of leadership or governance even before their contact with the Europeans. In all OruIgbo communities, the privileges accorded to cultural titles were well known (N.A.E:22). Needless to say, cultural titles, such as kingship in Oru-Igbo society conveyed more outstanding privileges (N.A.E:22). The very parochial views of some writers that tend to discredit African indigenous style of leadership is, without doubt, a clear reflection of how human mind could be limited and dysfunctional when it is driven by prejudice. The historical facts in Oru-Igbo and other places in the Western Igboland remain a very potent instrument in terms of justifying the claims made with respect to Oru-Igbo expertise and ingenuity in the craft of leadership as it related to indigenous system of leadership.

\section{Oru-Igbo and Benin Kingship Relations}

Much has been written about the relation between the Western Igbo and their neighbours, especially the Benin in the pre-colonial period. ${ }^{10}$ This is because both of them had fervent interactions which cut across all spheres. Prior to the final migration of the Oru-Igbo in the $15^{\text {th }}$ century, they were said to have lived with their other kith and kin at Benin and

\footnotetext{
${ }^{10}$ The following are some of the works done but do not conspicuously and sufficiently represent Oru-lgbo relation with the Western Igbo and Edo: Basden, G.T. 1966. Niger Igbos. London: FrankCass, Afigbo, A.E. 1981. Ropes of Sand.Nsukka: University of Nigeria Press, Afigbo, A.E. 1987. The Igbo and Their Neighbours. Ibadan: University Press Limited, Eyisi, M.C. 2010. Igbo History. Onitsha: Chuvic Publishers, Nzimiro, I. 1972. Studies in Igbo Political System: Chieftaincy and Politics in Four Niger States. London: Frankcass, Odigbo, A.D. 2001. Reformed OmerifeNdiOru/Oguta: Case Study on OmerifeNkwesi. Onitsha: Noben Publisher, Azogu, A.N. 1992. Oguta Cultural Heritage andPractice. Onitsha: Varsity Industrial Press, Ndupu,A.O. 2001. A Short Cultural History of Oguta. Enugu: Snaap Press Ltd etc.
} 
Western Igboland. All of them were regarded as one as they shared common history, culture and identity. However, much has not been clearly written to reflect the identity of Oru-Igbo or their link with their kith and kith in today's Delta State and other parts of Igboland. Based on the abundant evidences available, it is crystal clear that both OruIgbo and Benin had an extensive interaction at some points in time. However, it is obvious that what transpired between the Oru-Igbo and Benin was cultural blending. One could, therefore, say that Oru-Igbo people at Benin or Ado naIdu were part of the Igbo people that migrated from the East of the Niger to the Western Igboland in the pre-colonial era. If they were of Benin extraction as some postulate or claim, they would have preserved their Benin language the same way they have been able to maintain their kingship relation. Little wonder, the study of Oru- Benin kingship could serve as a veritable tool in deconstructing the erroneous aspects of Oru-Igbo history.

Prior to the final migration of Oru-Igbo people from their initial abode in Ado naIdu in the pre-colonial era, (N.A.E: 12) Oru-Igbo people interacted with different people including Benin indigenes. Besides their interaction with the core Benin indigenes, they also interacted with their Western Igbo kith and kin who dwelled around that region. As a result of such interactions, various Western Igbo communities adopted similar kingship system which was patterned after Benin monarchy to an extent (Onumonu, 2012:95). Certain attributes of the institution of kingship in Oru-Igbo were suggestive of an early knowledge of the functions of Benin monarch in the pre-colonial period. The Oba of Benin was revered by his people, but he was not absolute. When Ewuare came to the throne in the mid-fifteenth century, he introduced changes. He was a great magician, traveler and warrior. He was also powerful, courageous and sagacious. He "added to the physical splendor of monarchy by introducing red cloth and royal beads, and patronizing ivory carvers." In Oru-Igbo, Ezeigwe wore the above-described outfit as the major part of his official regalia. It is not a surprise that when Macgregor Laird saw Obi Ossai, King of Aboh in the same regalia he said, "From his fondness for coral ornament I should imagine him to be of Benin extraction ( Onumonu 2012:96) ." 
Moreover, the monarchical institution in Oru-Igbo was well-structured with various kingship emblems which did not exactly look like the kingship system in the other parts of Igboland. In fact, this sharp distinction could be regarded as the basis of argument for those that believe that Oru-Igbo people are not Igbo. Such argument is not peculiar with the Oru-Igbo people in the East of the Niger. It is also a known fact that some Western Igbo use their kingship link with Benin as a fact in proving their Benin origin. Be that as it may, other historical facts might remain controversial but the relationship between Oru-Igbo and Benin kingship cannot be a subject of dispute.

In addition, both Oru-Igbo and Benin kingship institutions were very sacred. That was the reason kings in Oru-Igbo were highly reverenced compared to their neighboring hinterland Igbo. ${ }^{11}$ For example, Oba was saluted as "he who kills a person the day he most values life." In consonance with the Benin system of saluting the Oba, the people of Oru-Igbo adopted almost the same method. The Ezeigwe was saluted as "Ogidiga" (a great king); 'Anya enu n' amaanyaaniura the upper eyelid that slaps the lower eyelid" - that is, "one whose power overshadows everyone." To crown it all, the Ezeigwe was saluted as "he who kills a person the day he most values life" - that is, "Ogbu Onye uboshi ndua naagu a". The Oba being not overruled had a political semblance at Obieze (parliament of the people) in Oru-Igbo where the people believed that the Ezeigwe could not err. In Benin, it was forbidden for the king (Oba) to touch the ground as a mark of respect and dignity to the monarch. Similarly at Oru-Igbo, it was an abomination for the Ezeigwe to fall on the ground. There was 'an incident when EzeEroa (an Ezeigwe in Oguta town) came out of his palace, stumbled and fell in the presence of his daughter and her companions, who were punished on the decision of the Okparas (elders) for using the insulting phrase - "UyaemenaEzeEroa" - EzeEroa had met his fate (Ndupu,2001:43).

From the foregoing, it is evident that Oru-Igbo and Benin had things in common with respect to kingship. Without doubt, the

\footnotetext{
${ }^{11}$ ObasiOsita (75 years) of Nnebukwu town in Oguta LGA, Imo State, interviewed on $22^{\text {nd }}$ February 2014, at Nnebukwu
} 
ancestors of Oru-Igbo had close and deep knowledge of the Benin socio-political norms before they left Benin area. Kingship in Oru-Igbo had much in common with some Igbo kingdoms in the Niger Delta area and in the West Igboland of Nigeria. These kingdoms must have modeled their institutions to a considerable extent on those of their neighbors. As a result of this cultural fusion, some Igbo-speaking people claim, according to their traditions that their ancestors came from Benin. Moreover, whereas the Igbo East of the Niger had no kings - an Igbo proverb has it, "Ndi Igbo EchiEze", that is, the Igbo make no king but Oru-Igbo on East of the Niger had a society patterned after the Igbo-speaking riverine communities to the West of the Niger that had semi-divine kingship of Benin (Onumonu, 2012:97).

Moreover, one would tend to believe that the linking of OruIgbo kingship to that of Benin is tenable. This is because, despite the numbers of years Oru-Igbo people spent in the East of the Niger after their migrations from Western Igboland, their kingship heritage remained very rich and unique. Though they were surrounded by the hinterland Igbo, their blend of Benin kingship was conspicuous in different ways. Therefore, it can be argued that their kingship heritage that separated them from other hinterland Igbo was not a coincidence. The comprehensive nature of Oru-Igbo kingship cannot be compared with the kingship system of hinterland Igbo as it were. Again, the above analysis proves wrong those that are of the opinion that Oru-Igbo people did not have contact with Benin in the past. The kingship emblems and the unique component of her kingship institution are valid facts one cannot overemphasize. If the Oru-Igbo kingship was not influenced at all by Benin kingly culture, then one would wonder why Oru-Igbo having migrated to their present place of settlement several years ago maintain a distinct style of kingship different from the rest of the Igbo.

In the light of the above, Oru-Igbo people could be regarded as one of the Western Igbo whose kingship was influenced by the Benin Empire (kingship). The idea of Benin influence on Oru-Igbo has been disputed by some other scholars. In some other quarters, however, it is believed that the Oru-Igbo people were the ones that rather influenced Benin people. In addition to the above, it is believed that the Oru-Igbo 
and their kith and kin in today's Delta State were together in the East of the Niger before their migration into the Western Igboland in the precolonial era. On this basis, therefore, one cannot dismiss the fact that both Oru-Igbo and Benin cultures had a commensurate influence on each other. Little wonder, the adoption of "Benin-like kingship" by the Oru-Igbo cannot in any way be seen as an imposition. What might have informed such development could definitely be the proximity of OruIgbo settlement to Benin in the pre-colonial era. This fact, therefore suggests, that Oru-Igbo also influenced the Benin kingship hence both of them lived close to each other.

\section{Evolution of Kingship in Oru-Igbo}

The kingship in Oru-Igbo had undergone various processes of transformation within the time frame of this research. As a result of changes in the society, Oru-Igbo had adjusted in no fewer ways in order to comply with the changing trends of each epoch. Though Oru-Igbo adopted a semblance of Benin kingship, but her exposure to other cultures around the Western Igboland, and East of the Niger had impacted on her kingship in one way or the other. Without doubt, these exposures and experiences could be considered as the reason Oru-Igbo kingship had some elements of Igbo and Benin culture. However, it would be appropriate to reiterate that despite her encounter with the above-mentioned cultures, the Benin aspect remain the dominant feature of Oru-Igbo kingship. This same feature of kingship is said to be the same with that of their kith and kin in today's Delta state.

During the period of roll back migration which involved all the Oru-Igbo communities into different areas in the Western Igboland, various Oru-Igbo communities organized themselves with their separate kings. Prior to the migration, they already had good knowledge of kingship. Upon their decision to migrate backward to the area they came from, ${ }^{12}$ the elders of the various towns in Oru-Igbo that migrated

\footnotetext{
${ }^{12}$ It is believed that Oru-Igbo migrated from the East of the Niger into the West of the Niger where they settled down for sometime before advancing to Benin and other places in that region in the pre-colonial era. Therefore, their movement backward to the East of the Niger is considered as the secondary
} 
from Ado naIdu ensured that there was prompt and decisive leadership. One could attribute the quick response in view of the clash of interest in Ado naIdu between the Ika Igbo (which Oru-Igbo was part of) and the Benin people as a pointer to their early kingship experience as each community of Oru-Igbo did not find it difficult to install their king. The various kings in Oru-Igbo towns that migrated from Ado naIdu led the various Oru-Igbo communities back to Western Igboland before they finally located the place now referred to as Oru-Igbo land via River Niger. Upon their accession to their offices, they took up their responsibility of administration which included execution of war. ${ }^{13}$

The interaction Oru-Igbo people had with their kith and kin in today's Delta state could be the reason Oru-Igbo kingship and that of the their Western Igbo kinsmen are similar. In the final phase of OruIgbo migration which led them to their present abode, various communities in Oru-Igbo that migrated from Ado naIdu were ruled by their own separate kings. They were able to embark on this final phase of migration successfully despite the aggressive confrontations they faced on their way. Their kings who also led them as warlords ensured that the people were kept together. The rate of their advancement was based on the pace each king maintained. They did not move at the same pace but each king ensured they maintained their aged long bond. In other words, the kings at this point played a dual role: they functioned as the administrative head as well as the warlords. At his juncture, the kingship in Oru-Igbo was purely like that of their kith and kin in today's Delta State and with the semblance of that of their neighbour (Benin people) at Ado naIdu ${ }^{14}$

Considering the massive responsibilities kings were saddled with at this phase as seen above, one would understand the reason kings were highly respected irrespective of their informal education. This also explains the reason kingship was not meant for people devoid of some

migration of the Oru-Igbo who are now domiciled in Oguta of today's Imo State, Nigeria.

${ }^{13}$ ObasiOsita (75 years) of Nnebukwu town in Oguta L.G.A., Imo State, interviewed on $22^{\text {nd }}$ February 2015, at Nnebukwu

14 Dele Odigbo (C.60 years) the Ezeigwe of Nkwesi town in Oguta L.G.A, Imo State interview on $23^{\text {rd }}$ March 2014 
attributes in terms of being able to relate well with individuals and group of people as well as possessing a critical mind that can deliver sound judgment, at anytime, anywhere and under any condition. It also suggests that the process of becoming a king was highly rigorous. Therefore, it was a very difficult task as they could not have risked their collective interest on the altar of politics. In addition, the reason each community in Oru-Igbo had a separate and independent king might be for the sake of smooth and effective administration. With the wave of events at that moment, the idea of decentralization could be considered as a very important element of governance needed at that point in time. As it is known in administration, decentralization enhances effective leadership especially when it has to do with taking or making quick decisions. The cooperation they offered to themselves especially during wars, even when they got to their final place of settlement goes a long way in demonstrating that they had been together as one people right from Ado naIdu and other places they stayed at the Western Igboland .

In the pre-colonial era, Oru-Igbo kings were known and addressed as Atamanya. They were eulogised with such words: Nwaojimmadunagoro 'who ascend the throne with a human head'. The change of the name became necessary when the King of Ngegwu from Oguta community killed the son of Mmagwuruaku, a woman from Umuasogu of Nnebukwu community ${ }^{15}$, who was married to Nkweke from Umudei ${ }^{16}$ Oguta, EzeAgadagba popularly called "Ezeanuubenwa",

\footnotetext{
${ }^{15} \mathrm{Nnebukwu}$ community is one of the communities that make up Oru-lgbo in Oguta Local Government Area of Imo State, Nigeria.

${ }^{16}$ Umudei is a royal village found in all the Oru-lgbo communities of Oguta Local Government Area of Imo State. It is also one of the distinctive cultural elements common with the Oru-Igbo all over Igboland, such as the Oru-Igbo at the West of the Niger. This without doubt, distinguishes them from the non Oru-Igbo in Igboland. Unlike other Igbo, the Umudei (royal village) are the ones that rightfully produce kings in Oru-Igbo. The process is a very organized such that a king is being produced when necessary without much problem or political complication. However, it is important to point that in the later years, like the post-colonial era, some power tussle was associated with the process of producing a king. This could be attributed to modernism and the economic benefit attached to kingship.
} 
'a king who does not hear the cry of a child'. This king killed the child on his night outing when the child was crying at the middle of the night $^{17}$. He pierced the child with his spear. As a result of that, the king was dethroned and the kingship was transferred from Ngegwu to Umudei. The first Umudei man from Oguta community to be crowned king was EzeNkweke, the man whose son was killed (Onumonu, 2012:99).

In view of the above, this kind of action could be seen as one of the reasons some people believe that Oru-Igbo kings in the pre-colonial era wield enormous limitless power. It has been often times used as a basis of comparison between Benin kings and Oru-Igbo kings as people believe that Benin kings were excessively powerful in the pre-colonial era. Nevertheless, it is equally imperative to assert that such assumption about Oru-Igbo kings might not reflect the exact powers of kings in Oru-Igbo after all. If kings were excessively powerful or had operated like emperor, the particular king in Oru-Igbo who was dethroned would have used his absolute powers to maintain his position. His dethronement could be regarded as impeachment in a modern parlance or system of democracy. On the other hand, based on the characteristics of government or act of governance that existed then, it could be inferred that democracy is not exclusively derived from Western political system as some Eurocentric writers would want people to believe. As far back in the pre-colonial dispensation, democracy was likewise practiced with a robust mechanism of checks and balances as vividly reflected in Oru-Igbo kingship system. This idea of separation of power (checks and balances) is practically visible in the functions of the various kingly officials in today's Oru-Igbo. Nevertheless, one cannot successfully research on this discourse without making a reference to the efforts made at building the process of the system at the earlier stages of kingship institution most especially in the pre-colonial and colonial eras.

${ }^{17}$ During the pre-colonial era in Oru-lgbo, the king routinely went out in the night in accordance with the cultural practice to perform some sacrifice or perform some rituals as the case may be. Such nights were regarded as sacred nights expected to be void of any form of noise. In such occasion, any being that interrupted the night or outing of the king was punished. 


\section{Kingship in Colonial Oru-Igbo}

During the colonial era, the Obis otherwise known as Ezeigwes ${ }^{18}$ did not actively involve themselves in the colonial politics. They were known as the custodians of Oru-Igbo tradition. Their major concern was to ensure the people live in peace through their monarchical leadership. They were held in high esteem because the people saw them as the custodian of Oru-Igbo tradition and the representatives of their ancestors. Besides, the Ezeigwe was considered as the father of all, he ensured peace and justice did not elude the people. Unlike other Ezeigwes, the Ezeigwe in Oru-Igbo was not a product of warrant chief $^{19}$. Without doubt, there were no central traditional authorities like Eze institution in Igboland with the exception of Oru-Igbo before colonialism. However, parts of Igboland that could be said to have established the equivalent of "village kingdoms" with monarchs were Nri, Arochukwu, Asaba, Agbor, Issele-Ukwu, Issele-Azagba, IsseleMkpituime, Onitsha, Ossomari and Aboh. ${ }^{20}$

\footnotetext{
${ }^{18}$ Perhaps, the adoption of Ezeigwe in the colonial era was as a result of the influence of the hinterland Igbo who surrounded Oru-Igbo people in Oguta area. In other words, the term Ezeigwe became common in Oru-Igbo in the colonial era. They did not use the coinage when they were in the Western Igbo land. In another vein, it is possible that they used the word before they migrated to the Western Igboland in the pre-colonial period. The hinter land Igbo are without doubt, more in number in the South East of Nigeria where Oru-Igbo people pitched their tenth since the pre-colonial era and it would not be a thing of surprise if such influence is exacted on them.

${ }^{19}$ Generally, colonial era witnessed a swift distortion of traditional institution in Igboland. This was the period when the colonial government made used of the warrant chiefs. In most case, the colonial administration did not put the tradition of the people into consideration in terms of appointing warrant chiefs. In Oru-Igbo in the pre-colonial time, the warrant chiefs were not as prominent as they were in other parts of Igboland. This was possible because there were already an established kingship institution in Oru-lgbo long before the arrival of the colonial masters.

20 Samuel Ojikeoya (101 years) of EziOrsu town in Oguta L.G.A. Imo State at his residence on $28^{\text {th }}$ December, 2011
} 
Be that as it may, in the colonial era (and before colonial era), kings in Oru-Igbo were generally addressed as Obi. The appellation 'Obi' was not peculiar to Oru-Igbo people alone. Their kith and kin in the Western Igboland and Onitsha were known with the above mentioned title as a way of addressing a king ${ }^{21}$. Interestingly, it could be said that Oru-Igbo people and their kith and kin had shared sociopolitical experience and other values together at some points before their departure to different places. The long standing tradition of OruIgbo and her kith and kin despite their separate location strengthens this analysis and gives a credible insight into their historical background. In addition, the enduring legacy of Oru-Igbo despite their deep integration with the core Igboland, speaks volume of their undiluted passion for cultural heritage and preservation.

Moreover, unlike in the pre-colonial days where 'physical might was much cherished as one of the qualities for a candidate of kingship, the colonial era was rather not so. The emphasis was instead laid on attributes considered more important for kingship candidates in accordance with Oru-Igbo tradition. The less attention paid to physical might could be attributed to the realities of colonial era. The era, without doubt, exposed Oru-Igbo people to the influx of non Oru-Igbo people of various origins. The convergence of different people in OruIgbo at this point led to the various socio-economic and political developments carried out in Oru-Igbo. Such developments, therefore, required some level of exposure on the side of the leadership for effective interaction and administration. Consequent upon this, the choice of a war-like king became inconsequential. The preference of a king with other qualities other than his 'physical might' cannot be divorced from the fact that wars were not common in the colonial era as compared to the pre-colonial era.

The parliament or the assembly of the people which was held outside the king's palace in pre-colonial times was later on transferred to the king's palace (Obieze). According to tradition, the change came when the military chiefs, especially the Iyasara became very ambitious

\footnotetext{
${ }^{21}$ The feelings of an average Oru-lgbo person support these assertions. The field work in the course of gathering facts for this paper brought about this revelation.
} 
and started to challenge the king and his office. Since the Iyasara became potentially a rival of the king, the need to permanently relocate the parliament back to the king's palace (Obieze) became paramount (Ndupu,2001:157). One would dare say that the colonial era, to some extent, 'demystified' kings to an extent.

\section{Kingship in Postcolonial Oru-Igbo}

The post colonial period ushered in developments which had some influence on the traditional institution of kingship in Igboland. The developments in themselves were not what gave birth to monarchy or Ezeigweship as an institution in Oru-Igbo. The story of how British colonialism attempted to create 'Traditional Rulers' by introducing the so-called 'Warrant Chiefs' in Igboland is well known. In many places, the various households of the colonial warrant chief assumed the status of ruling houses claiming hereditary right of succession to the Eze stool of the created autonomous communities. Unlike the hinterland Igbo of which some of their Ezeigwes were products of colonial warrant chief (Harneit-Sievers, 1998:73), Oru-Igbo had had their kingship institution established and well developed before the advent of colonialism.

Without gainsaying, Oru-Igbo were one of the three communities in Igboland with a historically renowned system of centralized kingship. The other towns are Onitsha and Arochukwu. In the former Eastern Nigeria House of Chiefs, as constituted in 1963, only eight traditional rulers were recognized as first class chiefs. The Obi (Ezeigwe) of Oru-Igbo (Oguta) was one of them. Others were the Obi of Onitsha, the EzeAro of Arochukwu, the Obong of Calabar, the Amanyanabo of Opobo, the Amanyanabo of Kalabari, the Amanayanabo of Nembe and the Amanyanabo of Bonny (Azogu, 1992:15). Consequent upon this, it could be said that the Ezeigwe was saddled with dual responsibilities: he represented the interest of his people on political front and acted as the custodian of their tradition. In this regard, the government considered him as the royal father who had a stake in the affairs of the government. Nevertheless, there existed other Obis (Ezeigwes) in other Oru-Igbo communities at this epoch but the Ezeigwe of Oguta town was the one who represented Oru-Igbo as a whole in the House of Chief as seen above. Irrespective of the evolutionary trends that took place in Igboland with respect to kingship 
and its institution, the traditional status quo was maintained in OruIgbo. Due to the laid down rules and established tradition, the process was never truncated (Onumonu, 2012:101). This scenario, therefore, clearly sheds light on the unity of purpose that has existed in Oru-Igbo. The fact that the king from Oguta community was able to successfully represent all other Oru-Igbo communities at this epoch speaks volume of their oneness. In other word, unlike during their migration phase, the situation at this moment encouraged a singular representation at the Old Eastern House of Chiefs. What one could deduce from the above is that the nature of a particular situation would determine the response of a people. The Eastern House of Chiefs was dissolved along with all parliamentary institutions in Nigeria, after the military coup of January 15, 1966. (Herneit-Sievers,1998:73)

During the civil war years (1967 - 1970), holders of chieftaincy titles played little roles politically. The post civil war administration of the East-Central State (comprising the Igbo-speaking areas of the old Eastern Region) followed a programme of mobilization for reconstruction and development - as did the federal military government under General Yakubu Gowon at that time. Local participation in development was understood purely in 'modern' terms: it was believed to mean mobilization partly by a strong state, partly through self-help by Town (Development) Union and other communal associations. This concept left little room for a formal inclusion of holders of chieftaincy titles in local government (Harneit-Sievers, 1998: 63). In a nutshell, this was how Town Union became part of Oru-Igbo traditional institution. Since then, Oru-Igbo custom has embraced the concept which had also enriched the institution in form of 'modern' leadership'. In Oru-Igbo and other Igbo communities, the major objectives of Town Union hinged on welfare and general development of the community. However, the Town Union worked in consonance with the tradition of Oru-Igbo people as well as acknowledged the place of the Ezeigwe in Oru-Igbo.

Official recognition of and political backing for chieftaincy institutions (Ezeigweship) in the case of Oru-Igbo people returned in the course of the Nigeria-wide local government reform of 1976 that created structures still existing today. This reform wanted to 'bring 
government closer to the people', and to strengthen the role of the local level as a third tier of government, beside the Federal and State level. 'Traditional rulers, as the Udoji Public Service Review Commission had put it in 1974, were believed to be important, even in the context of a development-oriented society, to act as 'the impartial fathers of their communities and embodiment of local custom'. This policy was applied not only in the North and Southwest, with their strong traditions of chieftaincy but in the Southeast as well. In the Igbo-speaking Anambra and Imo States (created in 1975 out of the former East-central State), a fourth level below that of the Local Government Area was subsequently introduced by the creation of 'autonomous communities.' It was on this level that Traditional Rulers were officially recognized, with only one Traditional Ruler in any single autonomous community, and standards for their recognition set up. The establishment of autonomous communities and the installation of Traditional Rulers was the outcome of recommendations made by a committee consisting of academics and civil servants in 1976 (Anambra State of Nigeria, 1976; Anambra/Imo States of Nigeria, 1976). Its chairman was the most prominent historian of Igbo Society, Adiele E. Afigbo, then professor at the University of Nigeria, Nsukka (Harneit-Sievers, 1998:63-64). In this vein, the various communities in Oru-Igbo with the exception of Kalabari Beach/Aro Quarter, assumed the status of autonomous communities. It was on this basis also that the various autonomous communities had the privilege of having an Ezeigwe as a representative of each town at the state level.

Consequently, from 1976 till 1991, traditional rulers (Ezeigwes) were officially recognized, in a somewhat standardized form. They were regarded as embodiment of local custom in administrativelydefined autonomous communities, such as Oru-Igbo communities. They acted as patrons and mediators within the community and served as transmission belt for government policies into the local sphere (HarneitSievers,1998:73). The Ezeigwes in Oru-Igbo actively engaged in the representation of their people's aspirations and interest as they spoke at the capacity of mouthpiece. The Ezeigwes at this era actively served as the link between the people and the state government. Unlike in the era of Old Eastern Region where only the Obi (Ezeigwe) of Oguta town represented all the other Oru-Igbo communities in the 'House of 
Chiefs', this dispensation offered all the Oru-Igbo communities (except Kalabari Beach/AroQuater) the privilege of having their Ezeigwes as their representatives. Kalabari Beach/Aro Quarter as an extension ${ }^{22}$ of Nnebukwu community did not have an Ezeigwe who represented them at the state level because it has not assumed the status of an autonomous community. Kalabari Beach/Aro Quarter was rather known as a municipal community. This in itself could be an indicator to the fact that the remaining six Oru-Igbo communities have a tie and bound that kept them together from Ado naIdu and other areas in the Western Igboland where they migrated from.

Generally, this period could be seen as a threshold to kingship institution in Igboland. The reformation and recommendation made by the government brought about uniformity to an extent in Igboland in terms of traditional rulership. However, the reformation cannot be said to have had the same effect in all Igboland. This is because Oru-Igbo people had already had an established and well organized kingship institution they brought from Ado naIdu and Western Igbo land. In the light of this, it is a known fact that Oru-Igbo kingship had always been hereditary and not a brainchild or product of colonialism or warrant chief as the case may be. Unlike the hinterland Igbo, the Royal Family (Umudei $^{23}$ had the prerogative of producing an Ezeigwe in all the Oru-

\footnotetext{
${ }^{22}$ Kalabari Beach and its environs (Aro Quarters and Motel area) are extension of Nnebukwu. Based on the general knowledge that exist in Oru-lgbo, it is a well established fact that in the course of Oru-Igbo migration in the precolonial era into their present area (Oguta area), Oshikpa people otherwise known as Nnebukwu people (now domiciled in Nnebukwu town) were the ones who first settled in the above-mentioned areas. On this note, therefore, those places are regarded as an extension of Nnebukwu because they have the right of ownership of those areas based on their privilege of first occupation during the final migration of Oru-Igbo people from the Western Igboland. Nevertheless, the above-mentioned places have over years been occupied by settlers from across different parts of Igboland who have been integrated into Oru-lgbo.

${ }^{23}$ Unlike in other part of Igboland where kings were politically selected, OruIgbo kings were selected based on their privilege of being part of a royal family (Umudei). The political nature of kingship among the hinterland Igbo
} 
Igbo communities. This culture had been a longstanding tradition that had existed in Ado naIdu and various places in the Western Igboland where they migrated from. This buttresses the reason Oru-Igbo people strictly maintained the status quo as it related to installing an Ezeigwe. In other words, the necessary qualifications and qualities of an Ezeigwe were never compromised. In this regard, it could be said that the Ezeigwes were saddled with the dual responsibilities: they represented their people as royal fathers in the Imo State government and acted as the custodian of the traditions of the people. The parameters for the stringent personal qualifying test of an Ezeigwe in Oru-Igbo included the following:

Both parents must have died.

He must be a member of the royal family.

He must be mentally fit with no physical deformity.

He must be married with male and female children.

He must have performed all the Age Grade ceremonies as well as IkeyeNmuo, IgbuAwaya and IgbuAkangbu titles.

He must have a suitable building.

He must not be a criminal or ex-convict.

He must not be financially embarrassed.

He must not be a drunk.

He must be a holder of the Igbuu (Ogbuagu) title (Akeru, 1999:7).

\section{Comparison on the Three Historical Stages in Oru-Igbo Kingship}

There existed changes at different stages of development on the kingship of Oru-Igbo. The stages are pre-colonial, colonial and postcolonial eras. During the pre-colonial era when Oru-Igbo people settled

could be regarded as a colonial legacy. But Oru-lgbo maintained their cultural legacy despite their position which had exposed them to the hinterland Igbo. In Oru-Igbo, the position of somebody or wealth does not confer on him the right of becoming a king. One has to first belong to the royal family before he can think of becoming a king. Without doubt, the ability the Oru-Igbo had to maintain their culture with respect to kingship shows how strong their culture had been. Thus, it also reiterates the fact that they so much cherish their cultural heritage which had survived in the midst of divergent cultures. 
with their other kith and kin in the Western Igboland now called Delta State, they had their kings which were like other Obis in the Western Igboland. At this point, they had moved from Benin to Ado naIdu. From Ado naIdu, they penetrated into various parts of WestenIgboland together with their other kith and kin in a form of backward movement. This movement and settlement of Oru-Igbo in different parts of Western Igboland enabled them to relate with other Igbo in the Western Igboland (Onumonu,2012:89). On this note, the convergence of all the Ika-Igbo ${ }^{24}$ at the Western Igboland served as a melting pot. The experience further cemented and unified the various kingship style practiced at Western Igboland. This means, therefore, that Oru-Igbo in the pre-colonial era at the Western Igboland had more of a kinship system that was quite different from other Igbo at the East of the Niger.

During the pre-colonial era, the Obi of Oru-Igbo was more respected as compared to the colonial and post colonial eras. Towering above every other reason perhaps is the fact that the Obis at that time were virtually looked up to for almost everything, including the execution of wars. Being at the head of leadership, the prestigious throne of the king was relied upon for general administration and protection of their land. The colonial era was an era of peculiar features that also determined the course of events at that moment. In the colonial era, Oru-Igbo had already secured her present abode through the migration they carried through the River Niger along the coast of Niger Delta of Nigeria. In this period, therefore, the practice of kingship in the Oru-Igbo was not completely different from what was obtainable in the Western Igboland $^{25}$.

Kingship in Oru-Igbo during the colonial era witnessed some level of influence from the colonial government which could be said to have robbed it of its traditional powers to an extent. The presence of the colonial masters and their laws could be considered as checks on the

\footnotetext{
${ }^{24}$ Oru-Igbo are part of Ika-Igbo by the reason of their settlement in the Western Igboland, close to the Benin Empire in the pre-colonial period when all the non-Benin people from the Western Igboland were collectively addressed and known as "Ika-lbo or Ika-Igbo".

${ }^{25}$ Ndupu Felix Chukwudifu (65 years) of Oguta Town in Oguta L.G.A, Imo State, interviewed on $12^{\text {th }}$ July, 2015
} 
Obi in Oru-Igbo. In the colonial era however, kingship was structured with arms in such a way that there was effective leadership. To this end, all the various communities in Oru-Igbo had developed their separate kingship institutions with little modification, though still in line with the Oru-Igbo culture. In this era, Kingship could be said to be conservative with lots of challenges. The wave of Christianity and education influenced people such that some certain practices associated with the kingly culture were questioned as fervent evangelism spread all over Oru-Igbo vigorously.

The post-colonial phase of Oru-Igbo kingship recorded massive modifications. This era could be regarded as a modern era of some sort. It was an era whereby modern touches were injected into Oru-Igbo kingship as an institution. In other words, various factors were reviewed with respect to how candidates emerge as kings acceptably. In this era, Kings were seen as the symbols of all Oru-Igbo communities. Unlike other eras, educational qualification became a very vital criterion for those aspiring to become kings in Oru-Igbo communities. In this regard, personalities who were highly educated with good background and social exposure gained advantage over those that did not have such qualities. Kingship institution became very attractive. Kings were greatly admired. Kingly attires and costumes were equally improved. Educated people were most preferred as kings in view of their responsibilities that involved serious administration and interactions with the state government. Again, the post-colonial era presented the kings with the privilege of receiving monthly allowance from the state government and other forms of benefits from different quarters. Having established the changing phases of each era with its peculiarity, it is evident that the glamour, glory and pressure associated with kingship institution in the later phase was unprecedented.

\section{Conclusion}

It is generally known and established (with few exception) that the Igbo society in the pre-colonial and colonial eras were regarded an acephalous society. This reality stems from the fact that they did not have kings or monarchs like the Oru-Igbo who at different epochs had a well structured system of governance with the Obi or Ezeigwe at the 
helm of affair. In other words, the non-Oru Igbo were rather governed by elders without a central figure like an Obi or Ezeigwe.

In a nutshell, both Oru-Igbo and their kith and kin in the area today called Anioma have similar social institutions, monarchy, cultural titles and philosophy of life to an extent. This cultural heritage was the strong instrument that galvanized both of them in all the places they met, which served as a melting pot. Little wonder, even after many years of their separation, the sense of brotherhood still reverberates in their conscience. In addition, their similar kingship system is a testimonial of their affinity.

Within the foregoing, it is also believed that Oru-Igbo lived in Ado naIdu (an area around the then Benin Empire) before they migrated to several areas in the Western Igboland. Their settlement in the Western Igboland which lasted for many years was a landmark in Igbo history. Therefore, based on their initial settlement in Ado naIdu, some, without concrete and much evidences, believe that Oru-Igbo were of Benin origin before their migration to the Western Igboland. The argument linking or ascribing Oru-Igbo identity to Benin or Edo is fast eroding. Such claim is always supported by referring to the type of Oru-Igbo kingship which has the semblance of Benin kingship. With all probability, one could posit that Oru-Igbo were among the Igbo that migrated in the pre-colonial era from Nri-Awka and Orlu complex, where it was believed that some Igbo people migrated from the other places, including Ado naIdu and other places in the Western Igboland.

The established kingship in Oru-Igbo was the reason Oru-Igbo did not share in the distortion of kingship (Ezeigweship) during the era of indirect rule. In other words, it has never existed in Oru-Igbo where a warrant chief not belonging to the royal family (umudei) became an Ezeigwe. The process of becoming an Ezeigwe or Obi was in accordance with the culture of Oru-Igbo without any element of distortion or controversy.

Without doubt, the paper has brought to fore the history of OruIgbo kingship institution in Imo State. The findings were predicated upon historical facts that appear quite revealing. The uniqueness and peculiarity of Oru-Igbo culture is that it has the blend of different cultures which makes it rich, enduring and encompassing. Such a rare 
quality is seen as the brain child of their historical evolution occasioned by their experiences in Ado naIdu (somewhere around Benin Empire), different parts of Western Igboland (areas in today's Delta State) and in their present location - now in the Southeast of Nigeria (N.AE:2) . Consequent upon this, the issue of identity sometimes becomes very controversial in Oru-Igbo. On concrete and practical terms, however, the people of Oru-Igbo do not really disassociate themselves from the Igbo nation, but when it comes to the issue of kingship as an institution and other cultural discourse, they rather prefer identifying themselves with their kith and kin (the Western Igbo) in today's Delta State and the Ogbaru people. Ogbaru people are said to be sub-cultural Igbo group who share similar riverine culture with Oru-Igbo people.

*Ugo Pascal Onumonu, Department of History, University of Ibadan, Ibadan, +2348067429348 


\section{References}

Adegbulu, F. 2011. "From Warrant Chief to Ezeship: A Distortion of

Traditional Institutions in Igboland" in Afro-Asian Journal of Social Sciences, Volume2, No.22, Quarter 11

Afigbo, A.E. 1981. Ropes of Sand.Nsukka: University of Nigeria Press Afigbo, A.E. 1987. The Igbo and their Neighbours. Ibadan: University Press Limited

Akeru, F. 1999. Brief History of Oguta.Owerri: Ricamak Business Venture

Azogu, A.N. 1992. Oguta Cultural Heritage and Practice. Onitsha: Varsity Industrial Press

Basden, G.T. 1966. Niger Igbo. London: Frank Cass and Co. Ltd Crowder, M. 1962.The Story of Nigeria. London: Faber and Faber Dele Odigbo, (c. 60 years) the Ezeigwe of Nkwesi town in Oguta L.G.A., Imo State, interviewed on $23^{\text {rd }}$ March 2012

Egbareba, J.U. 1992. "A Short History” in The History of Great Isi-IlleUku (Issele-Uku) Akeh-Osu, Onitsha: Etukowu Publishers Ltd Eyisi, M.C. 2010. Igbo History. Onitsha: Chuvic Publishers

Falola, T. (ed) 2000. African History Before 1885. Durham Carolina Academic Press

Falola, T. 2005. Nigerian History, Politics and Affairs, Asmara: Africa World Press, Inc

Harneit-Sievers, A 1998. "Igbo Traditional Rulers" Chieftaincy and the State in Southeastern Nigeria" in Africa Spectrum, Volume 33

Igwe, U. 2002. "Igboland Before 1800: An Appraisal" in History and Culture of Nigeria up to AD 2000. (eds) Osuntokun, A. ,Aworawo, D. Lagos: Frankad Publishers

Ijoma, J.O. 2002. "Igboland:A Historical Perspective" in A Survey of the Igbo Nation. (ed) Ofomata, G.E.K. Onisha: African First Publishers Limited

Imoagene, O. 1990.The Ibo of East Central Nigeria. Ibadan: New-Era Publishers

Isichei, E. 1977.History of West Africa Since 1800. London: Macmillian Educational Limited

Isichei, E. 1977.Igbo Worlds. London: Macmillian Educational Limited 
Jell-Bahlsen, S. 2008.The Water Goddess in Igbo Cosmology: Ogbuide of Oguta Lake. Asmara: Africa World Press, Inc

Samuel Ojikeoya, (years 101) of Eziorsu town in Oguta L.G.A., Imo State, interviewed on $28^{\text {th }}$ December, 2011

Samuel Ojikeoya, (101 years) of Eziorsu town in Oguta L.G.A., Imo State, interviewed on $28^{\text {th }}$ December, 2011

National Archives Enugu, EP10782A, Intelligence Report on Oguta Native Area. 1933-1934. P.22

Ndupu, A.O. 2001.A Short Cultural History of Oguta. Enugu: Snaap Press Ltd

Odiegbo, A.D. 2001. Reformed OmerifeNdiOru/ Oguta: Case Study on OmerifeNkwesi.Noben Publishers

Okwedume, C. 1994. Onicha-Ugbo. Lagos: Max-Henrie and Associates Ltd

Onumonu, U.P. 2012.“A History of Oru People in Imo State Up To 1991”. An M.A Dissertation, Department of History, University of Ibadan

Onyekpe, N. 2000. "Conflict and Cooperation Among West Niger Igbo Communities Before 1900" in Readings in Nigerian History and Culture. Oguntomisin G.O. and Ajayi S.A. Ibadan: Hope Publications

Obasi Osita, (75 years) of Nnebukwu town in L.G.A., Imo State, interviewed on $22^{\text {nd }}$ February, 2014 